\title{
THE KARYOTYPE OF THE PARASITOID Chelonus insularis Cresson (HYMENOPTERA, BRACONIDAE, CHELONINAE)
}

\author{
SILVA-JUNIOR, J. C., ${ }^{1}$ POMPOLO, S. das G., ${ }^{1}$ CAMPOS, L. A. de O. ${ }^{1}$ and CRUZ, I. ${ }^{2}$ \\ ${ }^{1}$ Departamento de Biologia Geral, Universidade Federal de Viçosa, CEP 36571-000, Viçosa, MG, Brazil \\ ${ }^{2}$ Centro Nacional de Pesquisa de Milho e Sorgo, EMBRAPA, CEP 35700-970, C.P. 151, \\ Sete Lagoas, MG, Brazil \\ Correpondence to: Juvenal Cordeiro Silva-Junior, Departamento de Ciências Biológicas, Universidade \\ Estadual do Sudoeste da Bahia - UESB, Rua José Moreira Sobrinho s/n, CEP 45.200-000, \\ Jequié, BA, Brazil, e-mail: juvenaljr@bol.com.br \\ (With 1 figure)
}

\begin{abstract}
The karyotype of Chelonus insularis (Hymenoptera, Braconidae, Cheloninae) is described. The males show an haploid number of seven chromosomes and the females a diploid number of fourteen chromosomes, confirming haplo-diploid sex determination. Comparisons of these results with karyotypes of other species of the same family were done and a possible mechanism involved in the karyotype evolution of this species is discussed.
\end{abstract}

Key words: cytogenetic, chromosome and sex determination.

\section{RESUMO}

\section{Cariótipo do parasitóide Chelonus insularis Cresson (Hymenoptera: Braconidae: Cheloninae)}

O cariótipo de Chelonus insularis (Hymenotera, Braconidae, Cheloninae) é descrito. Os machos apresentam um número haplóide de sete cromossomos e as fêmeas, um número diplóide de 14 cromossomos, confirmando o mecanismo haplodiplóide de determinação do sexo. Comparações entre esses resultados com cariótipos de outras espécies da mesma família foram feitas, e um possível mecanismo envolvido na evolução do cariótipo nesta espécie é discutido.

Palavras chave: citogenética, cromossomo e determinação do sexo.

\section{INTRODUCTION}

The subfamily Cheloninae comprises the internal parasitoids of Lepidoptera. The genus Chelonus is very large and includes many natural enemies of Lepidoptera which are considered pests of several crops. Jones (1985) observed numerous associations between the genus Chelonus and Spodoptera, like C. inanitus, a parasitoid of $S$. littoralis, S. exigua and $S$. frugiperda. Another example is Chelonus insularis which is an internal, arrhenotokous and solitary endoparasitoid insect, an important agent in the biological control of the fall armyworm, Spodoptera frugiperda (Lepidoptera, Noctuidae), a pest that causes severe damages in corn fields in Brazil. Cruz et al. (1991) studied the potential parasitism as an agent of biological control of $S$. frugiperda and found that parasitism in laboratory conditions was very significant (86\%).

Although the Braconidae is a large family and its members provide human benefits, there are several species that remain cytogenetically unknown, despite several cytogenetic studies have been done in this family. The present study aims at determining the karyotype of Chelonus insularis.

\section{MATERIAL AND METHODS}

This study was conducted using individuals from fall armyworm egg masses parasitized by mated females of $C$. insularis collected at maize 
fields of the Centro Nacional de Pesquisa de Milho e Sorgo (CNPMS), Sete Lagoas, Minas Gerais State, South-eastearn Brazil.

Chromosome squashes were obtained from cerebral ganglia of larvae in prepupal phase using the Imai et al. (1988) technique that consists of taking off the cerebral ganglia of prepupa and keeping it in a hypotonic-colchicine solution for two and a half hours. The material is then fixed and, after 24 hours, stained with Giemsa. Such technique was originally developed for ants, but it works with bees and wasps as well (Hoshiba \& Imai, 1993; Pompolo \& Campos, 1995; Gomes et al., 1995).

A
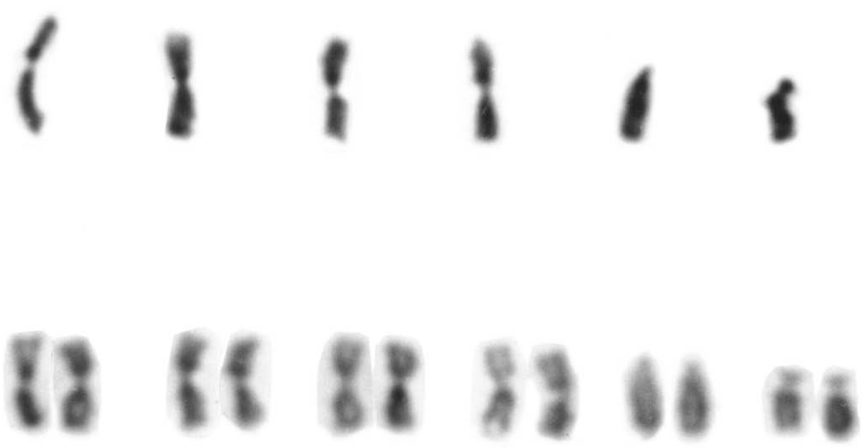

Fig. 1 - Karytotype of Chelonus insularis: (A) male $(n=7)$ and $(B)$ female $(2 \mathrm{n}=14)$. Bar $=5 \mu \mathrm{m}$.

\section{DISCUSSION}

The Braconidae presents significant cytogenetic variation among its various taxa. Gokhman \& Quicke (1995) pointed out that the variation in the haploid chromosome number ranges from 4 to 7 in the subfamilies Aphidiinae and Charmontinae and in the genus Rhysipolis, from 8 to 11 in the subfamilies Braconinae (Habrobracon), Meteorinae (Meteorus) and Miracinae (Mirax) and from 12 to 17 in the subfamilies Dorictynae (Heterospilus), Alysiinae and Microgastrinae.

The chromosome number found in $C$. insularis has already been observed in two other species: Aphidius rhopalosiphi and Ephedrus sp. (Gokhman \& Quicke, 1995). Comparing the karyotype of $C$. insularis with Meteorus versicolor (showing $\mathrm{n}=8$ inferred from the figure presented by Gokhman \& Quicke, 1995), it could be noted that the difference in chromosome number is due to one additional pair of a very small acrocentric chromosome present in the M. versicolor.

A good correlation among all the other pairs, the four metacentrics and the two telocentrics, was observed. Based on these data, a mechanism promoting such difference could be a result of a fusion mechanism. In this case, taking into consideration the modal theory of karyotype evolution (Matthey, 1973), and the chromosome number presented by the species on the subfamilies Braconinae e Meteorinae, the haploid number of 10 could be considered as the chromosome number present in the ancestral of these two subfamilies. From this modal number, fusion mechanisms could have originated new karyotypes, like the ones of $C$. insularis $(\mathrm{n}=7)$ e $M$. versicolor $(\mathrm{n}=8)$.

Similar hypothesis like this will only be validated if new cytogenetics studies would be made mainly with species of the same family. 
Cytogenetics studies in parasitic wasps have increased in the last years and their importance to the karyotype evolution studies and taxonomic and phylogenetic approaches has been demonstrated. Further analysis should be done in more species in order to have a broader picture of the patterns involved in the evolution of the karyotype in this interesting group.

Acknowledgments - This work was supported by CNPq, EMBRAPA/CNPMS, FAPEMIG and UFMA.

\section{REFERENCES}

CRUZ, I., REZENDE, M. A. A. \& DELLA LUCIA, T. M. C., 1991, Biologia de Chelonus (Chelonus) insularis (Cresson 1865), parasitóide de ovo/lagarta de Spodoptera frugiperda. In: Congresso Brasileiro de Entomologia: Simpósio Internacional sobre bicudo do algodoeiro, 1: Encontro sobre "Cochonilha" da palma forrageira, 2: Encontro sobre moscas-de-frutas, 2, Fevereiro 1991, Recife, Sociedade Entomológica do Brasil, 264p.

GOKHMAN, V. E. \& QUICKE, D. L. J., 1995, The last twenty years of Parasitic Hymenoptera karyology: an update and phylogenetic implications. J. Hym. Res., 4: 41-63.
GOMES, L. F., POMPOLO, S. G. \& CAMPOS, L. A. O., 1995, Cytogenetic analysis of three species of Trypoxylon (Trypoxylon) (Hymenoptera, Sphecidae, Larrinae). Rev. Bras. Genet., 18: 173-176.

HOSHIBA, H. \& IMAI, H. T., 1993, Chromosome evolution of bees and wasps (Hymenoptera, Apocrita) on the basis of C-banding pattern analyses. Jpn. J. Ent., 61: $465-492$.

IMAI, H. T., TAYLOR, R. W., CROSLAND, M. W. J. \& CROZIER, R. H., 1988, Modes of spontaneous chromosomal mutation and karyotype evolution in ants with reference to the minimum interaction hypothesis. Jpn. J. Genet., 63: 159-185.

JONES, D., 1985, Endocrine interaction between host (Lepidoptera) and parasite (Cheloninae, Hymenoptera); Is the host or the parasite in control? Ann. Ent. Soc. Amer, 78: 141-148.

MATTHEY, R., 1973, The chromosome formulae of eutherian mammals. In: A. B. Chiarelli \& E. Capanna (eds.), Cytotaxonomy and Vertebrate Evolution. Academic Press, London.

POMPOLO, S. G. \& CAMPOS, L. A. O., 1995, Karyotypes of two species of stingless bees, Leurotrigona muelleri and Leurotrigona pusilla (Hymenoptera, Meliponinae). Rev. Bras. Genet., 18: 181-184. 